\title{
ANALISIS PENGARUH FAKTOR MAKRO EKONOMI TERHADAP RETURN SAHAM PADA SEKTOR PROPERTI YANG TERDAFTAR DI BURSA EFEK INDONESIA PERIODE 2014-2017
}

\author{
Daniel Phen \\ Program Studi Magister Manajemen Universitas Tarumanegara \\ danielphen7@gmail.com
}

\begin{abstract}
The primary objective of this research is to study the influence of macroeconomic factors toward stock return of property, construction and real estate sectoral index in Indonesia Stock Exchange for 2014 until 2017. The variables for macroeconomic factors included inflation, interest rates, exchange rates, and Consumer Confidence Index. This research use multiple linear regression analysis method. The result of this research showed that inflation, interest rates, exchange rates, and Consumer Confidence Index simultaneously have significant effect toward stock returns. Partially, the research showed that only exchange rates has significant effect toward stock returns, while inflation, interest rates, and Consumer Confidence Index have no significant effect toward stock returns.
\end{abstract}

Keywords : macroeconomic, inflation, interest rates, exchange rates, Consumer Confidence Index, stock returns, multiple linear regression analysis

\begin{abstract}
Abstrak : Tujuan utama dari penelitian ini adalah untuk mempelajari pengaruh faktor makroekonomi terhadap return saham di indeks sektoral property, konstruksi, dan real estat yang terdaftar di Bursa Efek Indonesia periode 2014-2017. Variabel-variabel makroekonomi dalam penelitian ini adalah, inflasi, suku bunga, nilai tukar, dan Indeks Keyakinan Konsumen. Penelitian ini menggunakan metode analisis regresi linear berganda. Hasil penelitian ini menunjukkan bahwa inflasi, suku bunga, nilai tukar, dan Indeks Keyakinan Konsumen mempunyai pengaruh signifikan terhadap return saham secara bersama-sama. Secara parsial hanya nilai tukar yang mempunyai pengaruh signifikan terhadap return saham, sedangkan inflasi, suku bunga, dan Indeks Keyakinan Konsumen tidak mempunyai pengaruh signifikan terhadap return saham.
\end{abstract}

Kata Kunci : makroekonomi, inflasi, suku bunga, nilai tukar, Indeks Keyakinan Konsumen, return saham, analisis regresi linear berganda

\section{PENDAHULUAN}

Industri properti di Indonesia selalu menjadi daya tarik masyarakat dalam berinvestasi dikarenakan harga properti yang terus mengalami kenaikan. Namun keterbatasan dana menjadi hambatan untuk calon investor berinvestasi di industri properti. Alternatif yang bisa digunakan oleh masyarakat untuk berinvestasi di industri properti adalah investasi di saham sektor properti. Dana yang diperlukan untuk berinvestasi di saham properti tidaklah besar dan bisa lansung terjual. Selain itu investor juga bisa mendapatkan return dan dividen. Hal-hal ini membuat investasi saham di sektor properti menjadi menarik untuk masyarakat. Investor berinvestasi untuk mendapatkan return, tetapi return jarang bisa diprediksi secara pasti. Selalu ada resiko didalam semua investasi (Bodie, Kane, \& marcus, 2009). Untuk meminimalisir resiko dalam berinvestasi terdapat faktor-faktor dalam makroekonomi yang bisa mempengaruhi return saham. Faktor-faktor tersebut adalah inflasi, tingkat suku bunga, nilai tukar dan Indeks Keyakinan Konsumen. 


\section{TINJAUAN PUSTAKA}

Investasi adalah uang atau sumber daya yang dipakai untuk membeli aset dengan tujuan untuk menghasilkan penghasilan di masa yang akan datang (Petersen, 2017). Menurut (Gitman, et al., 2011) tipe-tipe investasi meliputi investasi properti, saham, obligasi, utang dan surat berharga. Menurut (Widoatmodjo, 2009) Saham merupakan salah satu komoditas keuangan yang diperdagangkan pasar modal. (Hadi, 2013) menyebutkan bahwa Saham merupakan surat berharga yang dapat dibeli atau dijual oleh perorangan atau lembaga di pasar tempat surat tersebut diperjual-belikan.

Menurut (Jogiyanto, 2008) return saham dapat didefinisikan sebagai hasil yang akan diperoleh dari kegiatan investasi saham. Sumber-sumber return investasi saham terdiri dari dua komponen utama, yaitu yield dan capital gain/loss. (Mishkin \& Eakins, 2015). Lingkungan makro ekonomi adalah lingkungan yang mempengaruhi operasi perusahaan sehari-hari (Tandelilin, 2010). Inflasi adalah kenaikan presentase rata-rata harga untuk semua barang dan jasa. (Rose \& Marquis, 2009). Bunga adalah beban atau biaya yang dibebankan kepada peminjam oleh pemberi pinjaman. Kurs tengah BI adalah kurs yang digunakan untuk mencatat nilai konversi mata uang asing dalam laporan keuangan perusahaan. Indeks Keyakinan Konsumen dikeluarkan oleh Departemen Statistik Bank Indonesia secara bulanan. Survei konsumen bertujuan untuk mengetahui keyakinan konsumen mengenai kondisi ekonomi saat ini.

Berdasarkan penelitian dari (Kurniadi, Achsani, \& Sasongko, 2013), (Sunaryo, 2013), dan (Abidin, 2016) yang menyatakan bahwa inflasi secara parsial tidak berpengaruh signifikan terhadap return saham. Sebaliknya hasil yang berbeda ditemukan pada penelitian dari (Ayu \& Suwarta, 2014), (Firdaus, 2011), (Simbolon \& Purwanto, 2018) dan (Pal \& Mittal, 2011) yang menemukan bahwa inflasi secara parsial berpengaruh signifikan terhadap return saham. Berdasarkan penelitian dari (Ayu \& Suwarta, 2014), (Sunaryo, 2013), dan (Firdaus, 2011) yang menemukan bahwa suku bunga secara parsial tidak berpengaruh signifikan terhadap return saham. Sebaliknya berdasarkan penelitian dari (Abidin, 2016), (Irawati, 2015), (Lesmana, 2013), (Simbolon \& Purwanto, 2018), dan (Pal \& Mittal, 2011) yang menemukan bahwa suku bunga secara parsial berpengaruh signifikan terhadap return saham.

Berdasarkan penelitian dari (Sunaryo, 2013), (Abidin, 2016), (Irawati, 2015), (Firdaus, 2011), (Simbolon \& Purwanto, 2018) dan (Pal \& Mittal, 2011) yang menemukan bahwa nilai tukar secara parsial berpengaruh signifikan terhadap return saham. Sebaliknya berdasarkan penelitian dari (Lesmana, 2013), dan (Kurniadi, Achsani, \& Sasongko, 2013) yang ditemukan bahwa nilai tukar secara parsial tidak berpengaruh signifikan terhadap return saham. Berdasarkan penelitian dari (Fisher \& Statman, 2003), dan (Sayim \& Rahman, 2015) yang menemukan bahwa Indeks Keyakinan Konsumen secara parsial berpengaruh signifikan terhadap return saham.

\section{METODE PENELITIAN}

Penelitian ini dibatasi pada indeks sektoral yang mengukur performa harga seluruh saham pada sektor properti, real estat, dan konstruksi bangunan yang terdaftar di Bursa Efek Indonesia pada tahun 2014-2017. Metode analisis data dengan uji asumsi klasik, regresi linier berganda, koefisien determinasi, uji t, dan uji f dari masing-masing variabel yang dibuat dengan SPSS versi 2.5. Uji t dilakukan untuk melihat pengaruh parsial dari variabel-variabel independen apakah berpengaruh signifikan terhadap variabel dependen. Apabila T hitung lebih besar dari $\mathrm{T}$ tabel maka dapat disimpulkan bahwa variabel-variabel independen tersebut berpengaruh secara signifikan terhadap variabel-variabel dependen. Kriteria pengujian jika signifikansi >0,05, maka Ho diterima dan jika signifikan <0,05, maka Ho ditolak. Berikut hipotesis untuk uji t tersebut adalah: 
Ho1 : Ada pengaruh signifikan antara Inflasi dengan return saham pada sektor properti.

Ho2 : Ada pengaruh signifikan antara suku bunga dengan return saham pada sektor properti.

Ho3 : Ada pengaruh signifikan antara nilai tukar dengan return saham pada sektor properti.

Ho4 : Ada pengaruh signifikan antara Indeks Keyakinan Konsumenterhadap return saham pada sektor properti.

Uji $\mathrm{F}$ berfungsi untuk mengetahui pengaruh simultan atau bersamaan dari variabelvariabel independen apakah berpengaruh signifikan terhadap variabel dependen. Apabila signifikansi $<0.05$ maka dapat disimpulkan bahwa variabel-variabel independen tersebut secara bersama-sama berpengaruh signifikan terhadap variable dependen. Berikut hipotesis untuk uji F tersebut adalah:

Ho5 : Secara bersama-sama terdapat pengaruh signifikan antara inflasi, suku bunga, nilai tukar dan Indeks Keyakinan Konsumen terhadap return saham pada sektor properti.

\section{PEMBAHASAN}

Sebelum dilakukan uji regresi linear berganda perlu dilakukan uji asumsi klasik sebagai syarat untuk melakukan uji regresi linear berganda. Berdasarkan analisis data menggunakan SPSS 25.0 ditemukan bahwa uji normalitas Kolmogorov-smirnov bernilai $0.200>0.05$ maka bisa dikatakan bahwa data penelitian terdistribusi normal. Uji multikolinearitas ditemukan nilai tolerance sebesar $0.927,0.399,0.476$, dan 0.426 lebih besar dari 0.1. Untuk nilai VIF pada masing-masing variabel independen sebesar 1.079, 2.504, 2.100, dan 2.347 lebih kecil dari 10. Maka dapat disimpulkan bahwa semua variabel independen tidak terjadi multikolinearitas. Uji heteroskedastisitas ditemukan nilai signifikansi masing-masing variabel sebesar $0.167,0,147$, 0.261 , dan 0,748 . Pada nilai alpha 0.05 terbukti bahwa masing-masing variabel independen tidak terkena heteroskedastisitas. Uji autokorelasi menggunakan Durbin Watson ditemukan nilai 1.887. Nilai ini akan dibandingkan dengan nilai pada tabel Durbin Watson dengan $\mathrm{N}=48$ dan variabel independen $4(\mathrm{k}=4)$. Dari tabel Durbin Watson diperoleh nilai dl $=1.369$ dan nilai $\mathrm{du}=1.720$. Maka didapat nilai $4-\mathrm{du}=2.280$. Setelah mendapat nilai tabel maka kita bisa menentukan apakah terjadi autokorelasi atau tidak dengan rumusan $1720<1887<2280$ yang berarti tidak terjadi autokorelasi.

Jika dilihat pada gambar 5 maka didapatkan persamaan regresi sebagai berikut:

\begin{tabular}{ccccc}
\multicolumn{4}{c}{ Y=0.57+1.24 Inflasi-0.209 } & Suku Bunga-3.298 Nilai Tukar-0.001 IKK. \\
\hline Inflasi & Suku Bunga & Nilai Tukar & IKK \\
\hline B & 1.24 & -0.209 & -3.298 & -0.001 \\
\hline \multicolumn{4}{c}{ Tabel 1. Hasil Uji Regresi Linear Berganda. }
\end{tabular}

Berdasarkan tabel 6 dapat dilihat bahwa variabel inflasi memiliki nilai sig. sebesar 0.356, jika dibandingkan dengan alpha 0.05 . Nilai sig. variabel inflasi lebih besar sehingga dapat disimpulkan bahwa inflasi secara parsial tidak berpengaruh signifkan dan positif terhadap return saham. Setelah itu dapat dilihat bahwa suku bunga memiliki nilai sig. 0.780, jika dibandingkan dengan alpha 0.05. Nilai sig. Variabel suku bunga lebih besar, sehingga dapat disimpulkan bahwa suku bunga secara parsial tidak berpengaruh signifikan dan negatif terhadap return saham. Variabel nilai tukar memiliki nilai sig. sebesar 0.01, jika dibandingkan dengan alpha 0.05. Nilai sig. variabel nilai tukar lebih kecil, sehingga dapat disimpulkan bahwa nilai tukar secara parsial berpengaruh signifikan dan negatif terhadap return saham. Variabel Indeks Keyakinan Konsumen memiliki nilai sig. sebesar 0.492, jika dibandingkan dengan alpha 0.05. Nilai sig. variabel Indeks Keyakinan Konsumen lebih besar, sehingga dapat disimpulkan bahwa Indeks Keyakinan Konsumen secara parsial tidak berpengaruh signifikan dan negatif terhadap return saham. 


\begin{tabular}{lllll}
\hline \hline & Inflasi & Suku Bunga & Nilai Tukar & IKK \\
\hline Sig. & 0.356 & 0.78 & -0.01 & 0.492 \\
\hline \multicolumn{5}{c}{ Tabel 2. Hasil Uji T }
\end{tabular}

Berdasarkan tabel 7 ditemukan bahwa nilai sig. untuk uji $\mathrm{F}$ adalah 0.016. Hal ini menandakan bahwa nilai sig. yang sebesar 0.016 lebih kecil dibanding alpha 0.05 . Berarti dapat disimpulkan bahwa variabel-variabel independen secara bersama-sama berpengaruh signifikan terhadap variabel dependen return saham. Dapat diartikan juga bahwa inflasi, suku bunga, nilai tukar, dan Indeks Keyakinan Konsumen secara bersama-sama berpengaruh signifikan terhadap return saham indeks sektoral.

\begin{tabular}{lc}
\hline Sig. & $\mathbf{0 . 0 1 6}$ \\
\hline & Tabel 3. Hasil Uji F
\end{tabular}

\section{KESIMPULAN}

Inflasi tidak memiliki hubungan signifikan dengan return saham disebabkan persepsi investor di negara negara berkembang berbeda dengan negara negara maju dalam menentukan pergerakan return saham. Tidak hanya ditentukan oleh kekuatan penawaran dan permintaan harga saham yang dapat menentukan return saham, tetapi juga dari variabel lainnya seperti kebijakan moneter suatu negara, faktor psikologis pasar, kondisi politik dan sosial, dan lain sebagainya.Suku bunga yang tinggi menyebabkan harga bahan baku menjadi mahal, dan perusahaan akan memilih alternatif pembiayaan yang lebih murah dan lebih efisien dengan harga jual yang tinggi sehingga tidak akan mempengaruhi profitabilitas perusahaan pada return saham yang akan diterima investor. Nilai tukar memberikan pengaruh terhadap IHSG terkait dengan ekspektasi investor terhadap perekonomian suatu negara. Misalnya jika nilai tukar rupiah terhadap dollar terdepresiasi (melemah), akan menimbulkan sikap was-was (khawatir) dikalangan investor. Bagi investor sendiri, depresiasi rupiah terhadap dollar menandakan bahwa prospek perekonomian Indonesia suram. Sebab depresiasi rupiah dapat terjadi apabila faktor fundamental perekonomian Indonesia tidaklah kuat, sehingga dollar Amerika akan menguat dan akan menurunkan IHSG di BEI. Indeks Keyakinan Konsumen tidak mempengaruhi return saham hal ini dikarenakan masih rendahnya keinginan masyarakat Indonesia untuk berinvestasi di saham. Berdasarkan survei yang dilakukan Bank Indonesia mengenai rencana penempatan kelebihan pendapatan. Ditemukan bahwa hanya sedikit masyarakat Indonesia yang ingin menempatkan kelebihan pendapatan mereka di investasi saham. Masyarakat Indonesia lebih memilih untuk menabung atau deposito, membeli emas, dan membeli properti dibanding berinvestasi di saham.

\section{DAFTAR PUSTAKA}

Abidin, M. Z. (2016). Analisis Pengaruh Faktor Fundamental dan Kondisi Makro Ekonomi Terhadap Return Saham. UNNES.

Ayu, I. G., \& Suwarta, I. K. (2014). Pengaruh Faktor Fundamental dan Ekonomi Makro Pada Return Saham Perusahaan Consumer Good. E-jurnal Akuntansi Universitas Udyana, 353-370.

Bodie, Z., Kane, A., \& Marcus, A. J. (2009). Investment eight edition. New york: McGrawHill.

Firdaus, M. D. (2011). Analisa Pengaruh Perubahan Interest Rate, dan Inflation Rate Terhadap Volatilitas Return Saham Industri Perbankan Di Indonesia. Binus.

Fisher, K. L., \& Statman, M. (2003). Consumer Confidence and Stock Returns. The Journal of Portofolio Management.

Gitman, L. J., Joehnk, M. D., Smart, S., Juchau, R. H., Ross, D. G., \& Wright, S. (2011). Fundamentals of Investing. Australia: Pearson Australia. 
Hadi, N. (2013). Pasar Modal. Yogyakarta: Graha Ilmu.

Irawati. (2015). Analisis Pengaruh Kinerja Keuangan Perusahaan dan Faktor Makro Ekonomi Terhadap Return Saham pada Sektor Industri Properti dan Real Estate yang Tercatat di BEI Tahun 2013. Binus.

Jogiyanto. (2008). Teori Portofolio dan analisis investasi. Yogyakarta: BPFE UGM.

Kurniadi, A., Achsani, N. A., \& Sasongko, H. (2013). Kinerja Keuangan Berbasis Penciptaan Nilai, Faktor Makroekonomi dan Pengaruhnya Terhadap Return Saham Sektor Pertanian. Jurnal Akuntansi dan Keuangan, 63-74.

Lesmana, L. (2013). Analisis Pengaruh Kinerja Keuangan Perusahaan dan Makro Ekonomi Terhadap Return Saham. Binus.

Mishkin, F. S., \& Eakins, S. G. (2015). Financial Markets and Institutions. London: Pearson Education.

Pal, k., \& Mittal, R. (2011). Impact of Macroeconomic Indicators on Indian Capital Markets. The Journal of Risk Finance, 84-97.

Rose, P. S., \& Marquis, M. H. (2009). Money and Capital Markets. New York: Mc Graw Hill. Sayim, M., \& Rahman, H. (2015). International Journal of Emerging Markets.

Sugiyono. (2012). Metode Penelitian Kualitatif Kuantitatif dan R\&D. Bandung: Alfabeta.

Sunaryo. (2013). Analisis Pengaruh Variabel-Variabel Ekonomi Makro Terhadap Return Saham. Binus Business Review, 541-550.

Tandelilin, E. (2010). Portofolio dan Investasi. Yogyakarta: Kanusius.

Widoatmodjo, S. (2009). Pasar Modal Indonesia Pengantar \& Studi Kasus. Bogor: Ghalia Indonesia. 